\title{
Endogenous Protective Mechanisms in Remodeling of Rat Heart Mitochondrial Membranes in the Acute Phase of Streptozotocin- Induced Diabetes
}

\author{
M. FERKO ${ }^{1}$, D. HABODÁSZOVÁ ${ }^{2}$, I. WACZULÍKOVÁ ${ }^{2}$, J. MUJKOŠOVÁ ${ }^{1}$, \\ J. KUCHARSKÁ ${ }^{3}$, L. ŠIKUROVÁ ${ }^{2}$, B. ZIEGELHÖFFER ${ }^{1}$, J. STYK ${ }^{1}$, A. ZIEGELHŐFFER ${ }^{1}$ \\ ${ }^{1}$ Institute for Heart Research, Center of Excellence in Cardiovascular Sciences, Slovak Academy of \\ Sciences, ${ }^{2}$ Department of Nuclear Physics and Biophysics, Faculty of Mathematics, Physics and \\ Informatics, Comenius University, ${ }^{3}$ Laboratory of Pharmacobiochemistry, Third Department of \\ Internal Medicine, Faculty of Medicine, Comenius University, Bratislava, Slovakia
}

Received January 25, 2008

Accepted March 25, 2008

On-line March 28, 2008

\begin{abstract}
Summary
The aim of present study was to investigate functional and physical alterations in membranes of heart mitochondria that are associated with remodeling of these organelles in acute phase of streptozotocin-induced diabetes and to elucidate the role of these changes in adaptation of the heart to acute streptozotocininduced diabetes (evaluated 8 days after single dose streptozotocin application to male Wistar rats). Action of free radicals on the respiratory chain of diabetic-heart mitochondria was manifested by $17 \%$ increase $(p<0.05)$ in oxidized form of the coenzyme $Q_{10}$ and resulted in a decrease of states S3 and S4 respiration, the respiratory control index, rate of phosphorylation (all $\mathrm{p}<0.01$ ) and the mitochondrial transmembrane potential $(p<0.05)$, but the ADP/O ratio decreased only moderately $(p>0.05)$. On the contrary, membrane fluidity and the total mitochondrial $\mathrm{Mg}^{2+}$-ATPase activity increased (both $\mathrm{p}<0.05$ ). In diabetic heart mitochondria, linear regression analysis revealed a reciprocal relationship between the increase in membrane fluidity and decrease in trans-membrane potential $(p<0.05, r=0.67)$. Changes in membrane fluidity, transmembrane potential, $\mathrm{Mg}^{2+}$ ATPase activity and the almost preserved $A D P / O$ ratio appear as the manifestation of endogenous protective mechanisms participating in the functional remodeling of mitochondria which contributes to adaptation of the heart to diabetes.
\end{abstract}

\section{Key words}

Diabetic rat • Heart mitochondria - Oxidative phosphorylation • Mitochondrial membrane fluidity - Mitochondrial transmembrane potential

\section{Corresponding author}

M. Ferko, Institute for Heart Research, Centre of Excellence in Cardiovascular Sciences, Slovak Academy of Sciences, Dúbravská cesta 9, P.O. Box 104, 84005 Bratislava 45, Slovakia. E-mail: usrdmife@savba.sk

\section{Introduction}

Heart in rats with acute streptozotocin-induced diabetes is characterized by altered metabolism (Kucharská et al. 2000, Stebelová et al. 2006, Volkovová et al. 1993, 1997, Ziegelhöffer et al. 1996, 1997, 2003a), changes in performance and susceptibility to additional pathological stimuli such as ischemia etc. (Andelová et al. 2006, Ravingerová et al. 2000, 2003) and by functional remodeling of their sarcolemmal (Ziegelhöffer et al. 1997) and mitochondrial membranes (Ferko et al. 2006a). Goals of the present study are: i) to investigate the changes induced by acute diabetes and/or remodeling in physical properties of mitochondrial membranes (such as the transmembrane potential and fluidity of membrane lipids) in relation to the capability of remodeled cardiac MIT to utilize oxygen and to synthesize ATP; ii) to check whether, and to what extent may be the formation of conjugated dienes in mitochondrial membrane lipids co-responsible for the changes associated with remodeling of diabetic heart mitochondria (MIT); iii) to elucidate the role that the observed changes may play in endogenous protective mechanisms securing the adaptation of heart to streptozotocin-induced diabetes.

\section{Methods}

All experiments were performed in accordance with the Guide for the Care and Use of Laboratory 
Animals published by the US National Institute of Health (NIH publication No. 85-23, revised 1985) as well as with the rules issued by the State Veterinary and Alimentary Administration of the Slovak Republic, basing on the law No 289/2003 of the Slovak Parliament.

Male Wistar rats (9-11 weeks old, $220 \pm 20 \mathrm{~g}$ b. wt.) were kept on 12/12 light/dark regimen, they were fed with standard pellet diet and had free access to water. Animals were made diabetic with a single dose of streptozotocin $(55 \mathrm{mg} / \mathrm{kg}$, i.p.). Diabetic state of the rats was controlled by estimation of glucose (BIO-LA-TEST, Glucose GOD 250, Pliva-Lachema, Brno, Czech Republic) and glycohemoglobin (Burrin et al. 1980) in the blood, as well as cholesterol (Watson 1960) and triacyglycerols (Fossati and Prencipe 1982) in the serum. Serum insulin was determined by commercial RIA kit (Linco Researech USA).

\section{Isolation of mitochondria (MIT)}

Hearts damped with small volume of ice-cold isolation solution (IS, containing in $\mathrm{mmol} / \mathrm{l}$ : $180 \mathrm{KCl}$, 4 EDTA and $1 \%$ bovine serum albumin, $\mathrm{pH}=7.4$ ) were cut into small pieces with scissors, transferred to a teflon/glas homogenizer together with $20 \mathrm{ml}$ of IS containing in addition protease (Sigma P 6141) $2.5 \mathrm{mg} / \mathrm{g}$ wet wt. (heart) and homogenized gently for 2-3 $\mathrm{min}$. After centrifugation at $1000 \mathrm{x}$ g for $10 \mathrm{~min}$ the protease containing supernatant, together with a part of MIT which were in a direct contact with the protease, was discarded. Pellet was resuspended in the same volume of IS but without protease, again homogenized and spunned down as previously. This supernatant containing now predominantly MIT, which were not in a direct contact with protease, was spunned down at $5000 \mathrm{x} \mathrm{g}$ for $15 \mathrm{~min}$. The pellet containing MIT was again resuspended in albumin-free IS containing only $180 \mathrm{mmol} / 1 \mathrm{KCl}$, $4 \mathrm{mmol} / 1$ EDTA and the final MIT fraction was spunned down at $5000 \mathrm{xg}$ for $15 \mathrm{~min}$. The isolation procedure was performed at $4{ }^{\circ} \mathrm{C}$.

$\mathrm{Mg}^{2+}$-dependent and 2, 4-dinitrophenol (DNP)stimulated ATPase (the total MIT ATPase) was assessed by estimation of $\mathrm{P}_{\mathrm{i}}$ liberated from ATP splitting (Ziegelhöffer et al. 1997). Contamination of the isolated MIT fraction by other subcellular membranes was tested via estimation of ATPase activities characteristic for the presence of sarcolemma $\left(\mathrm{Na}^{+}, \mathrm{K}^{+}\right.$-ATPase $)$and sarcoplasmic reticulum $\left(\mathrm{Mg}^{2+}-\mathrm{Ca}^{2+}\right.$-ATPase $)$ in the absence and presence of their specific inhibitors ouabain and thapsigargin (Máleková et al. 2007). Oxygen
Table 1. Levels of glucose and content of glycohemoglobin in the blood, levels of triacylglycerols, cholesterol and insulin in serum of rats with acute ( 8 days) streptozotocin diabetes.

\begin{tabular}{lcc}
\hline & Controls & Diabetes \\
\hline Glucose $(\mathrm{mmol} / \mathrm{l})$ & $5.13 \pm 0.15$ & $18.35 \pm 0.92^{*}$ \\
Glycohemoglobin $(\% \mathrm{Hb})$ & $4.11 \pm 0.13$ & $7.78 \pm 1.06^{*}$ \\
Triacylglycerols $(\mathrm{g} / \mathrm{l})$ & $1.21 \pm 0.09$ & $4.74 \pm 0.35^{*}$ \\
Cholesterol $(\mathrm{g} / \mathrm{l})$ & $1.70 \pm 0.11$ & $2.76 \pm 0.13^{*}$ \\
Insulin $(\mathrm{ng} / \mathrm{ml})$ & $1.04 \pm 0.15$ & $0.49 \pm 0.09^{*}$ \\
\hline
\end{tabular}

Data are means \pm S.E.M. from 15 experiments, $* p<0.01$ control vs. diabetic rats (Student's two-tailed test for unpaired observations).

consumption by isolated mitochondria was estimated by means of a Clark oxygen electrode (Gvozdjaková et al. 1984). Mitochondrial coenzyme $Q_{10} \quad\left(\mathrm{CoQ}_{10}\right)$ was determined by HPLC using the method of Lang et al. (1986). Membrane fluidity was assessed as the degree of fluorescence anisotropy using the fluorescent dye DPH (1, 6-diphenyl-1, 3, 5-hexatriene). Transmembrane potential of the mitochondria was monitored by confocal microscopy using carbocyanine (N, N'-di (3- trimethylammoniumpropyl) thiadicarbocyanine tribromide) as a fluorescent indicator; it was indicated as the fluorescence intensity ratio between $680 \mathrm{~nm}$ and $570 \mathrm{~nm}$ (aggregates/ monomers) of carbocyanine (Waczulíková et al. 2007).

\section{Statistics}

Results are given as means \pm S.E.M. Statistical significances were ascertained by using the Student's two-tailed test for unpaired observations. Only corrected $\mathrm{p}<0.05$ values were considered as significant.

\section{Chemicals}

If not specified differently in the text, all reagents and chemicals applied in the study were of analytical grade. Streptozotocin, EDTA and TRIS as well as the other chemicals, if not specified elsewhere, were purchased from Sigma-Aldrich USA.

\section{Results}

Diabetic state of experimental animals was confirmed by $258 \%$ elevation of blood glucose and $89 \%$ elevation in the total hemoglobin content. In addition, a $292 \%$ rise of triacylglycerols and a $62 \%$ increase of cholesterol in the serum were also observed in 
Table 2. Changes in functional properties of rat heart mitochondria induced by diabetes-caused remodeling.

\begin{tabular}{|c|c|c|c|}
\hline \multirow[t]{2}{*}{ Variable } & \multicolumn{2}{|c|}{ Results } & \multirow[t]{2}{*}{$\mathbf{p}$} \\
\hline & Controls & Diabetes & \\
\hline $\begin{array}{l}\mathrm{Co}_{10} \text { oxidized form } \\
\text { (mmol } \times \mathrm{mg}^{-1} \text { prot.) }\end{array}$ & $\begin{array}{c}0.472 \\
\pm 0.016\end{array}$ & $\begin{array}{l}0.559^{*} \\
\pm 0.017\end{array}$ & $<0.05$ \\
\hline $\begin{array}{l}\mathrm{QO}_{2}\left(\mathrm{~S}_{3}\right) \text {-glutamate } \\
\left(\text { (nAtO } \times \mathrm{mg}^{-1} \text { prot. } \times \mathrm{min}^{-1}\right)\end{array}$ & $\begin{array}{l}151.31 \\
\pm 4.31\end{array}$ & $\begin{array}{l}111.86 \\
\pm 3.93\end{array}$ & $<0.05$ \\
\hline $\begin{array}{l}\mathrm{QO}_{2}\left(\mathrm{~S}_{3}\right) \text {-succinate } \\
\left(\text { (nAtO } \times \mathrm{mg}^{-1} \text { prot. } \times \mathrm{min}^{-1}\right)\end{array}$ & $\begin{array}{l}238.64 \\
\pm 12.14\end{array}$ & $\begin{array}{l}188.72 \\
\pm 8.51\end{array}$ & $<0.05$ \\
\hline $\begin{array}{l}\mathrm{QO}_{2}\left(\mathrm{~S}_{4}\right) \text {-glutamate } \\
\left(\mathrm{nAtO} \times \mathrm{mg}^{-1} \text { prot. } \times \mathrm{min}^{-1}\right)\end{array}$ & $\begin{array}{c}35.7 \\
\pm 1.04\end{array}$ & $\begin{array}{r}25.26 \\
\pm 1.13\end{array}$ & $<0.05$ \\
\hline $\begin{array}{l}\mathrm{QO}_{2}\left(\mathrm{~S}_{3}\right) \text {-succinate } \\
\left(\text { nAtO } \times \mathrm{mg}^{-1} \text { prot. } \times \mathrm{min}^{-1}\right)\end{array}$ & $\begin{array}{l}132.33 \\
\pm 5.28\end{array}$ & $\begin{array}{l}112.72 \\
\pm 3.93\end{array}$ & $<0.05$ \\
\hline $\begin{array}{l}\text { Respiratory control index - } \\
\text { glutamate }\end{array}$ & $\begin{array}{c}5.375 \\
\pm 0.261\end{array}$ & $\begin{array}{c}4.415 \\
\pm 0.228\end{array}$ & $<0.05$ \\
\hline $\begin{array}{l}\text { Respiratory control index - } \\
\text { succinate }\end{array}$ & $\begin{aligned} & 1.8 \\
\pm & 0.039\end{aligned}$ & $\begin{aligned} & 1.67 \\
\pm & 0.028\end{aligned}$ & $<0.05$ \\
\hline $\begin{array}{l}\text { Phosphorylation rate - glutamate } \\
\left(\text { (nmol ATP } \times \mathrm{mg}^{-1} \text { prot. } \times \mathrm{min}^{-1}\right)\end{array}$ & $\begin{array}{l}362.66 \\
\pm 13.04\end{array}$ & $\begin{array}{l}262.97 \\
\pm 12.54\end{array}$ & $<0.05$ \\
\hline $\begin{array}{l}\text { Phosphorylation rate - succinate } \\
\left(\text { (nmol ATP } \times \mathrm{mg}^{-1} \text { prot. } \times \mathrm{min}^{-1}\right)\end{array}$ & $\begin{array}{l}322.89 \\
\pm 12.97\end{array}$ & $\begin{array}{l}243.46 \\
\pm 12.47\end{array}$ & $<0.05$ \\
\hline $\begin{array}{l}\text { ADP/O ratio - glutamate } \\
\left(n m o l A D P \times n A t O^{-1}\right)\end{array}$ & $\begin{array}{c}2.505 \\
\pm 0.261\end{array}$ & $\begin{array}{c}2.405 \\
\pm 0.228\end{array}$ & N.S. \\
\hline $\begin{array}{l}\text { ADP/O ratio - succinate } \\
\left(\text { nmol ADP } x n A t O^{-1}\right)\end{array}$ & $\begin{aligned} & 1.36 \\
\pm & 0.228\end{aligned}$ & $\begin{aligned} & 1.31 \\
\pm & 0.028\end{aligned}$ & N.S. \\
\hline $\begin{array}{l}M^{2+} \text {-ATPase } \\
\left(\mu \mathrm{mol} \text { P i } x g^{-1} \text { prot. } x h^{-1}\right)\end{array}$ & $\begin{array}{l}65.79 \\
\pm 1.12\end{array}$ & $\begin{array}{l}71.26^{*} \\
\pm 1.21\end{array}$ & $<0.05$ \\
\hline
\end{tabular}

Data are means \pm S.E.M. from 15 experiments. Statistical evaluation of control vs. diabetic rats was done using the Student's two-tailed test for unpaired observations. N.S. - not significant. Diabetes-induced increase variables is indicated by asterisks. All other variables were decreased in diabetic hearts.

comparison with controls. On the other hand, serum levels of insulin were decreased by $53 \%$ indicating an impairment of its secretion (Table 1).

The degree of contamination of MIT preparation by membranes of the sarcolemma and sarcoplasmic reticulum, estimated by presence of their marker enzymes amounted to $0.84 \%$ and $1.59 \%$, respectively (data not shown).

Due to a disconcert in unison of components of the electron-oxygen transport system (Tretter and AdamVizi 2004) free radicals induced a slight but significant $(p<0.05)$ increase in content of the oxidized form of $\mathrm{CoQ}_{10}$ and slowed down the flow of electrons in the respiratory chain. These perturbations diminished the oxygen consumption states 3 and 4 as well as the respiratory control index (RCI) and the rate of phosphorylation (all $\mathrm{p}<0.05$ or more), but they were not enough powerful to cause an uncoupling of oxidative phosphorylation, documented by a non-significant decrease of $\mathrm{ADP} / \mathrm{O}$ ratio, or to damage to mitochondrial $\mathrm{Mg}^{2+}$-ATPase (the reversely working ATP synthase). On the other hand, the activity of the latter enzyme became slightly but significantly increased $(\mathrm{p}<0.05$, Table 2 ).

Remodeling of the MIT in diabetic hearts also involved a significant $(p<0.05)$ increase in fluidity of the mitochondrial membrane (Fig. 1.). At the same time the MIT from diabetic animals exhibited significantly $(\mathrm{p}<0.001)$ lower transmembrane potential (Fig. 2.) as compared with MIT from control animals. Linear regression analysis of the latter findings revealed significant association $(p<0.05, r=0.67)$ between the increase of membrane fluidity and decrease of 


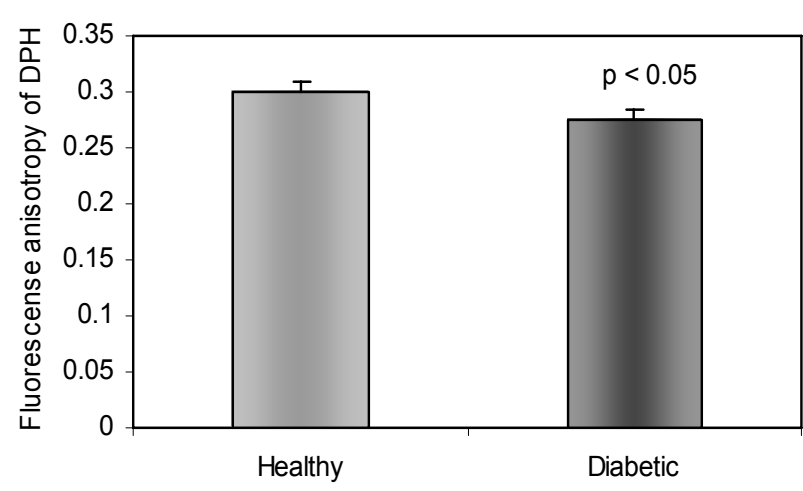

Fig. 1. Fluorescence anisotropy of $D P H$ in the mitochondrial membrane. Data are means \pm S.E.M. of 7 experiments.

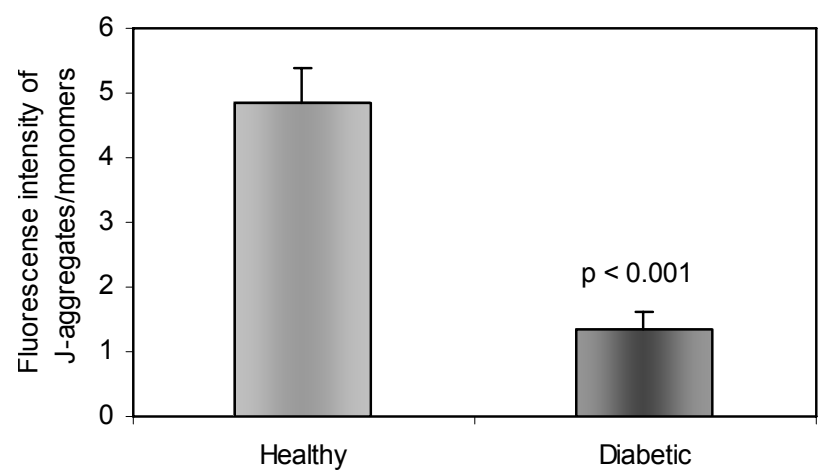

Fig. 2. Carbocyanine fluorescence intensity ratio aggregates/monomers $(680 \mathrm{~nm} / 570 \mathrm{~nm})$ in isolated heart mitochondria from healthy and diabetic rats. Data are means \pm S.E.M. of 7 experiments.

transmembrane potential. Testing the stability of transmembrane potential in control and diabetic heart MIT by gradual increase of the extramitochondrial concentration of $\mathrm{K}^{+}$ions (Fig. 3.) revealed that although the MIT from diabetic hearts have markedly lower transmembrane potential, they possess higher capability to keep it stable.

\section{Discussion}

The aim of the present study was to examine alterations characterizing the diabetes-induced remodeling of cardiac MIT and to identify those changes that are related to endogenous protection or adaptation to the disease itself. This task required an experimental protocol enabling to investigate exclusively the processes related to diabetes. However, it is well known, that similarly like in men, experimental diabetes is also accompanied by numerous complications. In many cases these spontaneously appearing complications may exert additive or amplifying effect on the alterations caused by
口 Healthy $\bullet$ DIA

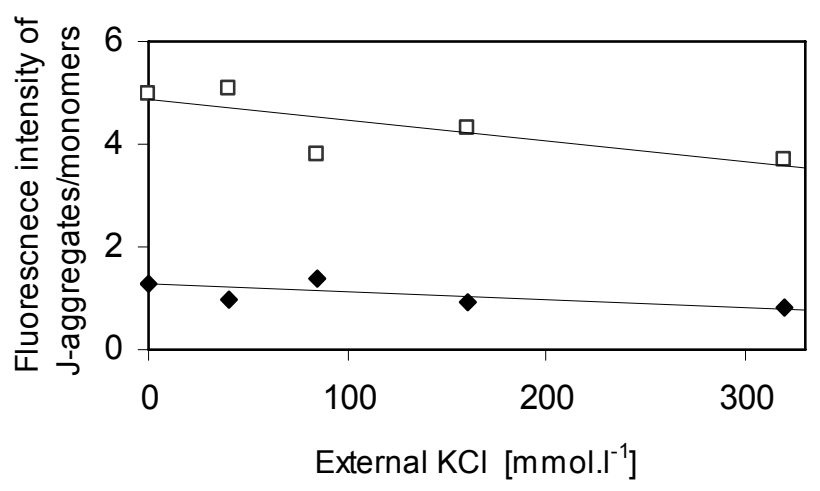

Fig. 3. Effect of $\mathrm{KCl}$ on stability of mitochondrial transmembrane potential in healthy and diabetic rat hearts.

the diabetes itself. For these reasons we focused our attention to the acute phase of diabetes when the disease was already fully developed (Table 1), but the diabetes accompanying complications were still not present in a measurable extent.

Due to disturbances in function of the respiratory chain the diabetic heart is not capable to utilize oxygen properly. Consequently, cardiac cells experience a situation resembling hypoxia (Juránek and Bezek 2005, Ziegelhöffer et al. 2005) in spite of the fact that the hypoxia is not caused by a decrease in tissue $\mathrm{pO}_{2}$. This state is known as pseudo-hypoxia. Because the high availability of oxygen does not allow a switch over to anaerobic energy production, cardiac cells would be suffering energy deficiency. To cope with this problem the diabetic heart is forced to activate endogenous protective mechanisms which are involved in functional remodeling of MIT (Ferko et al. 2006a). This remodeling requires changes in both chemical and physical properties of MIT membranes (Ferko et al. 2006b, Ziegelhöffer et al. 2005, 2007) coupled with a break in oxygen sensing of cardiac cells (Holotňáková et al. 2007).

The remodeling is usually understood as structural and functional deviations from the normal state that are caused by some pathological stimuli. Nevertheless, it was already demonstrated that not all remodeling-associated deviations from normal function are noxious. Some may belong to endogenous protective mechanisms and represent compensatory or even adaptation changes alleviating the effect of the given pathology (Ziegelhöffer et al. 1997, 2002, Waczulíková et al. 2002).

The increase observed in amount of the oxidized form of $\mathrm{CoQ}_{10}$ and the decrease in state 3 and state 4 oxygen consumption, as well as in respiratory control 
index and in the rate of phosphorylation (Table 2) could be considered without any doubt as pathological deviations. However, it was already demonstrated that in acute diabetes, the strength of the above mentioned damage may be considerably counteracted by augmented transfer of energy from cardiac MIT to the cytoplasma (Ziegelhöffer et al. 2005). The latter compensatory process is based on significant increase in the number of functionally still integrated substrate and energy transition pores (also termed as contact sites) in the mitochondrial membrane (Ziegelhöffer-Mihalovičová et al. 1997) and it is accompanied with an increase in fluidity of the mitochondrial membrane (Ziegelhöffer 2005). The observed increase in $\mathrm{Mg}^{2+}$-ATPase activity, is also contributing to the stabilization of coupling between the oxidation and phosphorylation (Ziegelhöffer et al. 2002, 2003b).

Our discovery of tight association between the fluidity and transmembrane potential of diabetic heart MIT does not inform only about the mutual interrelationship between these two physical variables but it also stresses their exclusive regulatory role in processes located in mitochondrial membranes. In the present case, their functional remodeling enables the diabetic heart to resist the pseudohypoxia. The observation of more stabile transmembrane potential in diabetes-remodeled heart MIT is in concert with the latter notion.

It may be summarized that the increase in membrane fluidity and in mitochondrial $\mathrm{Mg}^{2+}$-ATPase activity, as well as the stabilization of transmembrane potential in heart MIT, which are associated with acute functional remodeling of these organelles in streptozotocin-induced diabetes participate in endogenous protective mechanisms alleviating the effect of the disease. The presented new information may be helpful in search for such a treatment of diabetes that would utilize the endogenous protective mechanisms in the myocardium.

\section{Conflict of Interest}

There is no conflict of interest.

\section{Acknowledgements}

The valuable help of Mária Kollárová and Zlatica Hradecká is gratefully acknowledged. This study was supported by grants VEGA 1/3037/06, 2/5110/26, APVV 51-027404, SP 51/0280901.

\section{References}

ANDELOVÁ E, ONDREJČÁKOVÁ A, ADAMEOVÁ A, KUŽELOVÁ M, ŠVEC P, STYK J, RAVINGEROVÁ T: The effect of hypercholesterolemia and simvastatin on ischemic-reperfusion injury in rat hearts with experimental diabetes mellitus. Physiol Res 55: 13P, 2006.

BURRIN JM, WORTH R, ASHWORTH AA, CURTIS S, ALBERTI KG MM: Automated colorimetric estimation of glycosylated hemoglobin. Clin Chim Acta 106: 45-50, 1980.

FERKO M, GVOZDJAKOVÁ A, KUCHARSKÁ J, MUJKOŠOVÁ J, WACZULÍKOVÁ I, STYK J, RAVINGEROVÁ T, ZIEGELHÖFFER-MIHALOVIČOVÁ B, ZIEGELHÖFFER A: Functional remodeling of heart mitochondria in acute diabetes: interrelationship between damage, endogenous protection and adaptation. Gen Physiol Biophys 25: 397-413, 2006 a.

FERKO M, HABODÁSZOVÁ D, WACZULÍKOVÁ I, GVOZDJAKOVÁ A, KUCHARSKÁ J, MUJKOŠOVÁ J, ZIEGELHÖFFER A: Relationship between fluidity transmembrane potential and functional characterics of mitochondria in hearts of acute diabetes rats. Physiol Res 55: 19P, $2006 \mathrm{~b}$.

FOSSATI P, PRENCIPE L: Serum triglycerides determined colorimetrically with an enzyme that produces hydrogen peroxide. Clin Chim Acta 28: 2077-2080, 1982.

GVOZDJAKOVÁ A, BADA V, SÁNY L, KUCHARSKÁ J, KRUTÝ F, BOŽEK P, TRŠŤANSKÝ L, GVOZDJÁK J: Smoke cardiomyopathy: disturbance of oxidative process in myocardial mitochondria. Cardiovasc Res 18: 229-232, 1984.

HOLOTŇÁKOVÁ T, ZIEGELHÖFFER A, OHRADANOVÁ A, HULÍKOVÁ A, NOVÁKOVÁ M, PASTOREK J, PASTOREKOVÁ S: Induction of carbonic anhydrase IX by disruption of oxygen sensing in rat fibroblasts and cardiomyocytes. Pflügers Arch 456: 323-337, 2007.

JURÁNEK I, BEZEK Š: Controversy of free radical hypothesis: reactive oxygen species - cause or consequence of tissue injury? Gen Physiol Biophys 24: 263-278, 2005. 
KUCHARSKÁ J, BRAUNOVÁ Z, ULIČNÁ O, ZLATOŠ L, GVOZDJÁKOVÁ A: Deficit of coenzyme Q in heart and liver mitochondria of rats with streptozotocin-induced diabetes. Physiol Res 49: 411-418, 2000.

LANG JK, GOHIL K, PACKER L: Simultaneous determination of tocopherols, ubiquinols and ubiquinones in blood, plasma, tissue homogenates, and subcellular fractions. Anal Biochem 157: 106-116, 1986.

MÁLEKOVÁ L, KOMÍNKOVÁ V, FERKO M, ŠTEFÁNIK P, KRIŽANOVÁ O, ZIEGELHÖFFER A, SZEWCZYK A, ONDRIÁŠ K: Bongkrekic acid and atractyloside inhibits chloride channels in mitochondrial membranes of rat heart. Biochim Biophys Acta 1767: 31-44, 2007.

RAVINGEROVÁ T, ŠTETKA R, PANCZA D, ULIČNÁ O, ZIEGELHÖFFER A, STYK J: Susceptibility to ischemiainduced arrhythmias and the effect of preconditioning in the diabetic rat heart. Physiol Res 49: 607-616, 2000.

RAVINGEROVÁ T, NECKÁ $\breve{R}$ J, KOLÁ̌̆ F: Ischemic tolerance of rat hearts in acute and chronic phases of experimental diabetes. Mol Cell Biochem 249: 59-65, 2003.

STEBELOVÁ K, HERICHOVÁ I, ZEMAN M: Rhythmic changes of melatonin levels in plasma, pineal gland and peripheral tissues of rats with streptozotocin-induced diabetes. Physiol Res 55: 43P, 2006.

TRETTER I, ADAM-VIZI V: Mechanisms for endogenous production and elimination of reactive oxygen species in mitochondria. FEBS J 271 (Suppl 1): 198 (S4.10-05), 2004.

VOLKOVOVÁ K, CHORVÁTHOVÁ V, JURČOVIČOVÁ M, KÖSZEGHYOVÁ L, BOBEK P: Antioxidative state of the myocardium and kidneys in acute diabetic rats. Physiol Res 42: 251-255, 1993.

VOLKOVOVÁ K, ZIEGELHÖFFER A, STARUCHOVÁ M, ONDREIČKA R: Relationship between some biochemical parameters in blood and myocardial tissue and the tolerance of the heart to calcium in different stages of experimental diabetes (in Slovak). Kardiologia 6: 152-157, 1997.

WACZULÍKOVÁ I, ZIEGELHÖFFER A, ORSZÁGHOVÁ Z, ČÁRSKY J: Fluidising effect of resorcylidene aminoguanidine on sarcolemmal membranes in streptozotocin-diabetic rats: blunted adaptation of diabetic myocardium to $\mathrm{Ca}^{2+}$ overload. J Physiol Pharmacol 53: 727-739, 2002.

WACZULÍKOVÁ I, HABODÁSZOVÁ D, CAGALINEC M, FERKO M, ULIČNÁ O, MATEAŠÍK A, SIKUROVÁ L, ZIEGELHÖFFER A: Mitochondrial membrane fluidity, potential, and calcium transients in the myocardium from acute diabetic rats. Can J Physiol Pharmacol 85: 372-381, 2007.

WATSON D: A simple method for determination of serum cholesterol. Clin Chim Acta 5: 613-615, 1960.

ZIEGELHÖFFER A: Endogenous protective mechanisms in the heart triggered by acute streptozotocin-diabetes. In: Experimental Hypertension and Ischemic Heart Disease. BACHÁROVÁ L, KYSELOVIČ J, SLEZÁK J (eds), VEDA, Bratislava, 2005, pp 193-208.

ZIEGELHÖFFER A, RAVINGEROVÁ T, STYK J, TRIBULOVÁ N, VOLKOVOVÁ K, ŠEBOKOVÁ J, BREIER A: Diabetic cardiomyopathy in rats: biochemical mechanisms of increased tolerance to calcium overload. Diabetes Res Clin Pract 31 (Suppl): S93-S103, 1996.

ZIEGELHÖFFER A, RAVINGEROVÁ T, STYK J, ŠEBOKOVÁ J, WACZULÍKOVÁ I, BREIER A, DŽURBA A, VOLKOVOVÁ K, ČÁRSKY J, TURECKÝ L: Mechanisms that may be involved in calcium tolerance of the diabetic heart. Mol Cell Biochem 176: 91-98, 1997.

ZIEGELHÖFFER A, RAVINGEROVÁ T, WACZULÍKOVÁ I, ČÁRSKY J, NECKÁŘ J, ZIEGELHÖFFERMIHALOVIČOVÁ B, STYK J: Energy transfer in acute diabetic rat hearts. Adaptation to increased energy demands due to augmented calcium transients. Ann NY Acad Sci 967: 463-468, 2002.

ZIEGELHÖFFER A, BUNDGAARD H, RAVINGEROVÁ T, TRIBULOVÁ N, ENEVOLDSEN MT, KJELDSEN K: Diabetes and semi-starvation-induced changes in metabolism and regulation of Na,K-ATPase in rat heart. Diab Nutr Metab 16: 222-231, 2003a.

ZIEGELHÖFFER A, WACZULÍKOVÁ I, RAVINGEROVÁ T, ZIEGELHÖFFER-MIHALOVIČOVÁ B, NECKÁŘ J, STYK J: Augmented energy transfer in rat heart mitochondria: Compensatory response to abnormal household of energy in acute diabetes. In: Atherosclerosis, Hypertension and Diabetes. PIERCE GN, NAGANO M, ZAHRADKA P, DHALLA NS (eds), Kluwer Academic Publishers, Boston, 2003b, pp 439-453.

ZIEGELHÖFFER A, HOLOTŇÁKOVÁ T, PASTOREK J, PASTOREKOVÁ S, FERKO M, STYK J: Carbonic anhydrase IX up-regulation reveals hypoxia-like molecular responses in acute diabetic rat heart. $J$ Mol Cell Cardiol 38: 1085 (Abstr No.240), 2005. 
ZIEGELHÕFFER A, PECHÁŇOVÁ O, FERKO M, HOLOTŇÁKOVÁ T, MUJKOŠOVÁ J, WACZULÍKOVÁ I, PASTOREKOVÁ S: Mitochondrial signaling in diabetic rat heart: acute phase of the disease. $J$ Mol Cell Cardiol 42: 61, 2007.

ZIEGELHÖFFER-MIHALOVIČOVÁ B, OKRUHLICOVÁ L', TRIBULOVÁ N, RAVINGEROVÁ T, VOLKOVOVÁ K, ŠEBOKOVÁ J, ZIEGELHÕFFER A: Mitochondrial contact sites detected by creatine phosphokinase activity in hearts of normal and diabetic rats: is mitochondrial contact site formation a calcium-dependent process? Gen Physiol Biophys 16: 329-338, 1997. 